\title{
Spatial assessment of the potential risk of avian influenza A virus infection in three raptor species in Japan
}

\author{
Sachiko MORIGUCHI ${ }^{1) *}$, Manabu ONUMA ${ }^{2)}$ and Koichi GOKA ${ }^{1)}$ \\ 1) Invasive Alien Species Research Team, National Institute for Environmental Studies, 16-2 Onogawa, Tsukuba, Ibaraki 305-8506, Japan \\ ${ }^{2)}$ Ecological Genetics Research Section, Center for Environmental Biology and Ecosystem, National Institute for Environmental Studies, \\ 16-2 Onogawa, Tsukuba, Ibaraki 305-8506, Japan
}

(Received 18 September 2015/Accepted 2 March 2016/Published online in J-STAGE 14 March 2016)

\begin{abstract}
Avian influenza A, a highly pathogenic avian influenza, is a lethal infection in certain species of wild birds, including some endangered species. Raptors are susceptible to avian influenza, and spatial risk assessment of such species may be valuable for conservation planning. We used the maximum entropy approach to generate potential distribution models of three raptor species from presence-only data for the mountain hawk-eagle Nisaetus nipalensis, northern goshawk Accipiter gentilis and peregrine falcon Falco peregrinus, surveyed during the winter from 1996 to 2001. These potential distribution maps for raptors were superimposed on avian influenza A risk maps of Japan, created from data on incidence of the virus in wild birds throughout Japan from October 2010 to March 2011. The avian influenza A risk map for the mountain hawk-eagle showed that most regions of Japan had a low risk for avian influenza A. In contrast, the maps for the northern goshawk and peregrine falcon showed that their high-risk areas were distributed on the plains along the Sea of Japan and Pacific coast. We recommend enhanced surveillance for each raptor species in high-risk areas and immediate establishment of inspection systems. At the same time, ecological risk assessments that determine factors, such as the composition of prey species, and differential sensitivity of avian influenza A virus between bird species should provide multifaceted insights into the total risk assessment of endangered species. KEY WORDS: avian flu, endangered species, MaxEnt, niche modeling, species distribution model
\end{abstract}

doi: 10.1292/jvms.15-0551; J. Vet. Med. Sci. 78(7): 1107-1115, 2016

Emerging and re-emerging infectious diseases are serious threats to biodiversity, domestic animals and human health $[7,20]$. For example, chytridiomycosis has led to drastic declines in amphibian populations [8], and avian malaria and pox have driven endemic bird species to extinction or endangered status [60, 63]. Bovine spongiform encephalopathy (BSE) was responsible for the slaughter of 3.3 million cattle in the UK [10]. Moreover, human immunodeficiency virus (HIV) and the Ebola virus, which originated in Africa, have become global threats to human health [37]. Highly pathogenic avian influenza (HPAI) viruses of the H5N1 subtype (HPAI-H5N1) are considered emerging infectious diseases [43], and an epidemic could pose a major threat to poultry production, human health and endangered species $[3,32$, 52].

The natural hosts of avian influenza A viruses are believed to be ducks, shorebirds and gulls [4, 62]. Low pathogenic avian influenza (LPAI) has been endemic among wild birds for a relatively long time [62]. HPAI-H5N1 was first reported in 1996 in Chinese poultry [61], and both wild birds and poultry [18] may have spread the virus to various parts of the world $[4,32,57]$.

\footnotetext{
${ }^{*}$ Correspondence to: Moriguchi, S., Department of Environmental Science Graduate School of Science and Technology, Niigata University, 2-8050, Ikarashi, Nishi-ku, Niigata 950-2181, Japan. e-mail: rustica79@yahoo.co.jp C2016 The Japanese Society of Veterinary Science

This is an open-access article distributed under the terms of the Creative Commons Attribution Non-Commercial No Derivatives (by-nc-nd) License $<$ http://creativecommons.org/licenses/by-nc-nd/4.0/>.
}

HPAI-H5N1 infection has been lethal for some wild birds, including endangered species. In 2005, during the first largescale outbreak reported in wild birds, more than 6,000 birds died at Qinghai Lake in northwestern China [5], including black-necked cranes Grus nigricollis, which are classified as "Vulnerable" by the International Union for Conservation of Nature (IUCN) [26]. Moreover, in other places of the world, fatalities have also been noted in endangered species, such as the red-breasted goose Branta ruficollis, the saker falcon Falco cherrug (both of them are classified as "Endangered" [26]) and the grey-headed fish eagle Icthyophaga ichthyaetus (classified as "Near Threatened" [26]), as a result of HPAI-H5N1 infection [36, 52].

Raptor species have been especially vulnerable to HPAIH5N1. In the wild, mortality caused by the virus has been reported in the Eurasian sparrowhawk Accipiter nisus, common kestrel Falco tinnunculus and Eurasian eagle-owl Bubo bubo $[6,33]$. Several studies of experimental infection with HPAI-H5N1, via both intranasal inoculation and consumption of infected prey, revealed that raptors (American kestrel Falco sparverius [19] and gyrfalcon Falco rusticolus $\times$ saker falcon hybrids [1]) either died or showed severe neurological signs within 4-7 days. On the other hand, their vulnerability to LPAI subtypes has not been adequately assessed. This risk should be considered, however, as some studies have revealed that even in waterbirds, the LPAI virus can have negative effects (e.g. weight loss and delayed migration) $[34,59]$.

Species distribution models (SDMs), some of which have been created by the process of ecological niche modeling [48], provide a potentially useful warning of infection in wild 
birds and poultry, and could be used to identify priority areas for the surveillance of avian influenza A. In a previous study, we created a potential risk map for avian influenza A viruses (among others included incidence sites for HPAI-H5N1) that reflected their spread by migratory birds in Japan [44]. The vectors of HPAI-H5N1 infection in poultry are believed to be migratory birds (as opposed to transported live poultry), because outbreaks in Japan have been accompanied by similar outbreaks in Korea, and the viruses in both countries are more similar to each other genetically, than they are to other viruses that have occurred in the past [53]. In fact, potential risk indices for the introduction of avian influenza A showed a positive relationship in the dabbling duck population [44], which is considered a major vector of avian influenza A viruses [31].

In the present study, we created habitat suitability maps for three raptor species and superimposed them on the risk map for avian influenza A during the winter (created in our previous study) [44]. The target raptor species were the mountain hawk-eagle Nisaetus nipalensis, northern goshawk Accipiter gentilis and peregrine falcon Falco peregrinus, which succumbed to HPAI-H5N1 infection during the winter in Japan $[27,53,55]$. These species are native to Japan and spend the entire winter in various areas of the country [56]. They are all categorized as "Least Concern" by IUCN [26], because of their broad distribution; however, according to the Ministry of the Environment, Japan, the mountain hawk-eagle is categorized as an endangered species; the northern goshawk is nearly threatened, and the peregrine falcon is vulnerable [40]. The risk maps of the present study can suggest priority areas for habitat conservation and surveillance of avian influenza A infection in these species.

\section{MATERIALS AND METHODS}

Risk indices for avian influenza A virus: We used the risk indices for avian influenza A in wild birds from the invasion risk map of our previous study [44], which was estimated with a spatial resolution of $0.0962^{\circ}$ (about $10 \times 10 \mathrm{~km}$ ) using the logistic output and inherent untested assumption that tau $=0.5$. The risk indices were predicted using the maximum entropy approach (MaxEnt version 3.3.3e [49]). They were estimated within 64 localities where avian influenza A viruses (including HPAI-H5N1) had been reported in wild birds throughout Japan during the winter season (from October 2010 to March 2011) and were related to environmental variables for virus survival and host abundance (e.g. elevation and dabbling duck population). As a result, the area under the curve (AUC) of the created map was 0.78 , and the repeatability of the map was confirmed by comparing the risk indices of former incidence sites of avian influenza A with all other indices under investigation. Potential high-risk areas were identified in lowlands of western Japan and along the Pacific coast [44].

Environmental variables: The following explanatory variables were used in the analysis of the three raptors: elevation; annual average temperature; maximum snow depth; maximum angle of slope; edge length between forest and farmland; and proportion of river area. In addition, land use variables (proportion of forest, farmland and urban areas) were combined to provide independent predictor variables by principle component analysis, because they were significantly correlated with each other. The first (PC1 represented proportion of forest area: eigenvalue $=0.043$ and eigenvector $=0.98$ ); second $(\mathrm{PC} 2$ represented proportion of farmland area: eigenvalue $=0.006$ and eigenvector $=0.93$ ); and third (PC3 represented proportion of urban area: eigenvalue $=0.001$ and eigenvector $=0.96$ ) main components that represent each proportion of land use were also added.

Variables for the habitat suitability models for the three raptors were calculated from various databases. WorldClim data (resolution: 5 arc-min) [22], which provide global climate layers (e.g., temperature and precipitation) representative of the years 1950-2000 with high resolution (from 30 arc-sec to 10 arc-min), were used to create annual average temperature and elevation layers. The normal value of maximum snow depth from 1971-2000 was obtained from the Mesh Climatic Data 2000 [28]. The maximum angle of the slope layer was calculated from the elevation and slope angle data provided in 1981 (resolution: about $1 \times 1 \mathrm{~km}$ ) [41], because peregrine falcons prefer cliffs for both breeding and hunting $[17,29]$. Edge length between forest and farmland is one of the major variables of breeding density in northern goshawks, because these species use such environments for hunting [38]. The river, forest, farmland and urban areas are also considered as important habitats of raptors $[25,30,42,46,47,58]$. The area $\left(\mathrm{km}^{2}\right)$ of each grid cell was extracted from the Natural Environmental Information GIS surveys from 1979-1999 [14], and proportion of those areas to total land area were calculated. The urban area was defined as artificial areas, including residential, industrial and commercial zones. All environmental variables were resampled to the spatial resolution of $0.0962^{\circ}$ (about $10 \times$ $10 \mathrm{~km}$ ), and 5,162 grid cells were created because raptor occurrence data were collected from $10 \times 10 \mathrm{~km}$ grid cells. The all spatial analysis was carried out using ArcGIS 9.3.1 (ESRI Inc., Redlands, CA, U.S.A.).

To check multicollinearity, we calculated the Pearson's product-moment correlation matrix for all explanatory variables. If pairs of the variables have strong correlation $(r<0.5)$, either of them which could become explainable factors for habitat selection of the species and could remain more total explanatory variables were used for the subsequent analysis. All statistical analyses were carried out using R 2.13.1 [51].

Distribution of the raptors: We used the winter presence data (from October to March) from a total of 34 grid cells (about $10 \times 10 \mathrm{~km}$ ) for the mountain hawk-eagle, 57 for the northern goshawk and 42 for the peregrine falcon surveyed from 1996-2001, respectively, because avian influenza A outbreaks in wild birds have typically occurred during the winter in Japan [27]. Therefore, data from these raptor localities were collected during the wintering season (October to March from 1996-2001) from the Report of the distribution of Japanese animals (birds) in the National Survey on the Natural Environment [2] and BirdBase [23]. The former data were collected from field surveys, questionnaires to 
birdwatchers and literature; and the latter were collected from literature. In addition, there was a time lag between datasets for raptor presence and avian influenza A incidence; locality data for the three raptors were collected $10-15$ years before those of avian influenza A, which was used to predict the risk indices. However, the raptors' ranks in the red data list in Japan either remained the same (mountain hawk-eagle and peregrine falcon) or declined (northern goshawk) during the period 1998-2012 [40], and therefore, their distribution is not expected to have been reduced.

The records for each site were also resampled using the same grid cells used for the explanatory variables, because the ranges of those grid cells were different each other. All the explanatory variable values, latitudes and longitudes were extracted for each grid cell. They were then classified into 30 groups for the mountain hawk-eagle, 35 for the northern goshawk and 40 for the peregrine falcon by cluster analysis using R 2.13.1 [51], to avoid the use of similar environmental data in locations within close proximity to each other, which may cause spatial autocorrelation. One locality was selected for each group, and the 30, 35 and 40 localities were used as response variables for each raptor species.

Species distribution modeling: We used the maximum entropy approach (MaxEnt version 3.3.3e) [49] to develop distribution models from presence-only data. Because detection probabilities are expected to be low with one-day surveys, whether the species were present or not was checked only once per site. Therefore, any recorded absence might be a false absence. The maximum entropy approach has been reported to be superior to presence-only approaches [13] and is capable of providing highly accurate estimates even with small sample sizes [21]. We used $75 \%$ of the locations to compute 10 randomly chosen replicates for model construction; the remaining $25 \%$ of the locations were used for model validation, and each replicate of the model was iterated 10,000 times.

Using pseudo-absent sites as background data for target groups (i.e. mountain hawk-eagle, northern goshawk and peregrine falcon in the present study) is known to improve the model predictions for MaxEnt by alleviating sample selection bias $[12,50,64]$. All surveyed grid cells $(N=4,865)$ including breeding surveys were used as background datasets, and the results were extrapolated to all grid cells $(N=5,162)$ in Japan.

We evaluated the resulting model with receiver operating characteristic (ROC) curves by calculating the AUC; the threshold independent index ranged from 0.5 (random accuracy) to 1.0 (perfect discrimination).

The median potential suitable index of the models estimated with logistic outputs ( $\operatorname{tau}=0.5$ ) was used to produce a potential habitat suitability map for each raptor species. We also calculated global Moran's I coefficients for residuals of the estimated habitat suitability indices in each model to assess the strength of spatial autocorrelation using ArcGIS 9.3.1 (ESRI Inc.).

We created a map for each raptor species to suggest areas for surveillance of raptors, accounting for the impact of previous avian influenza A outbreaks. Map (avian influenza A risk map) indices were obtained for the product of risk indices for avian influenza A [44] and habitat suitability indices for each raptor species, which indicated spatially high-risk areas for avian influenza. Correlation coefficients were also calculated between habitat suitability indices and avian influenza A risk indices. Carcasses infected with HPAI-H5N1 have been reported for one mountain hawk-eagle, one northern goshawk and nine peregrine falcons in Japan $[27,53,55]$. These sites were illustrated in the risk map for each species to validate reliability of the maps.

\section{RESULTS}

For the models of habitat suitability, we used five environmental variables for the mountain hawk-eagle and northern goshawk and seven environmental variables for the peregrine falcon, all of which had correlation coefficients no greater than 0.5 . For the mountain hawk-eagle model, the AUC was 0.72 , with a standard deviation (SD) of 0.07 . For the northern goshawk model, the AUC was 0.71 with a SD of 0.08 , whereas for the peregrine falcon model, the AUC was 0.77 with a SD of 0.06 . Spatial autocorrelation was insignificant in all models (mountain hawk-eagle: Moran's $I=0.19, P=0.05$; northern goshawk: Moran's $I=0.23, P=0.08$;

Table 1. Average contributions of various environmental variables to the models. PCA analysis was generated to make three land use variables (represented proportion of forest, farmland and urban area) independent each other

\begin{tabular}{lccc}
\hline \multirow{2}{*}{ Environmental variable } & \multicolumn{3}{c}{ Contribution } \\
\cline { 2 - 4 } & Mountain hawk-eagle & Northern goshawk & Peregrine falcon \\
\hline Elevation & 66.3 & - & 38.6 \\
Annual average temperature & - & 35.8 & 4.5 \\
Maximum snow depth & 27.1 & - & - \\
Maximum angle of slope & - & - & 11.3 \\
Edge length between forest and farmland & - & 27.6 & - \\
Proportion of river area & 5.1 & - & 5.3 \\
PC1 represented proportion of forest area & 1.4 & 13.7 & 27.9 \\
PC2 represented proportion of farmland area & - & 9.0 & 6.2 \\
PC3 represented proportion of urban area & 0.1 & 13.9 & 6.2 \\
\hline
\end{tabular}


and peregrine falcon: Moran's $I=0.12, P=0.22$ ).

Among the environmental variables, the most effective predictors of potential distribution (more than 10\% contribution and in order of importance) were elevation and maximum snow depth for the mountain hawk-eagle; annual average temperature, edge length between forest and farmland, PC2 represented proportion of farmland area, PC3 represented proportion of urban area and PC1 represented proportion of forest area for the northern goshawk; and elevation, PC1 represented proportion of forest area and maximum angle of slope for the peregrine falcon (Table 1). The habitat suitability indices for the mountain hawk-eagle were positively correlated with elevation and negatively correlated with maximum snow depth of more than about $70 \mathrm{~cm}$ (Fig. 1). Indices for the northern goshawk were maximum at an annual average temperature of $15^{\circ} \mathrm{C}$ and a $50-\mathrm{km}$ edge length between forest and farmland, were negatively correlated with the $\mathrm{PC} 1$ represented proportion of forest area and the PC2 represented proportion of farmland area, and reflected the use of more than 0.5 of the PC3 represented proportion of the urban area (Fig. 2). Indices for the peregrine falcon were positively correlated with the maximum angle of the slope and negatively correlated with elevation and PC1 represented proportion of forest area (Fig. 3).

The risk map for the mountain hawk-eagle showed that most regions in Japan were at low risk for the incidence of avian influenza $\mathrm{A}$ in this species (Fig. 4a). In addition, habitat suitability indices were negatively correlated with avian influenza A risk indices $(r=-0.44, P<0.001)$ (Fig. 5a). In contrast, risk maps for the northern goshawk and peregrine

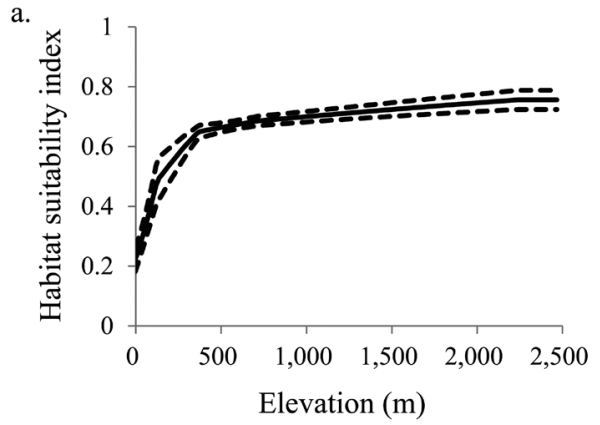

b.

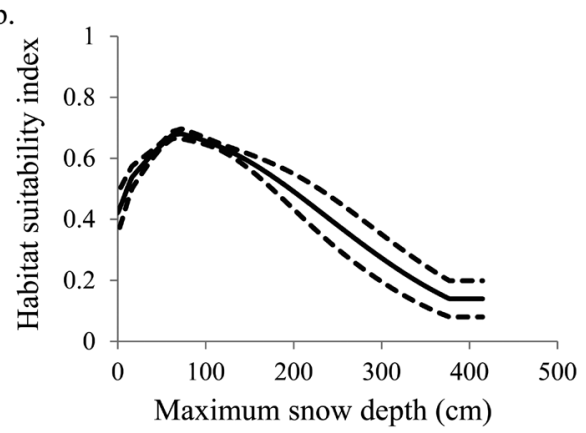

Fig. 1. Relationship between habitat suitability index of mountain hawk-eagle Nisaetus nipalensis, and (a) elevation, and (b) maximum snow depth. Solid lines represent the mean, and dotted lines represent the $95 \%$ confidence interval (CI). a.

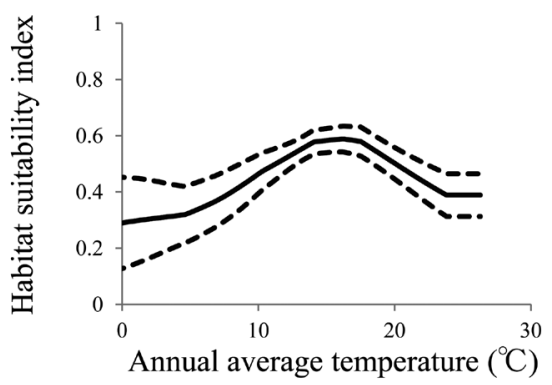

c.

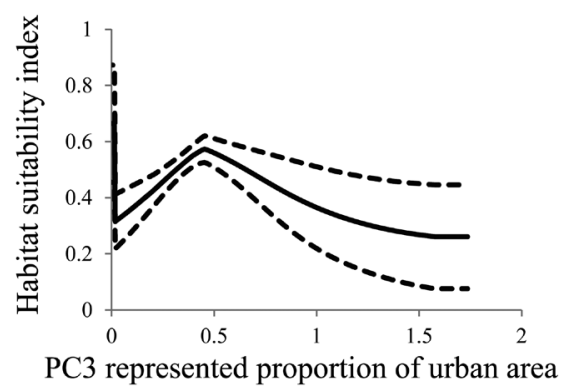

b.

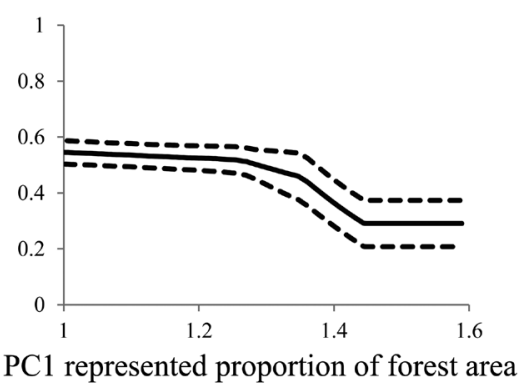

d.

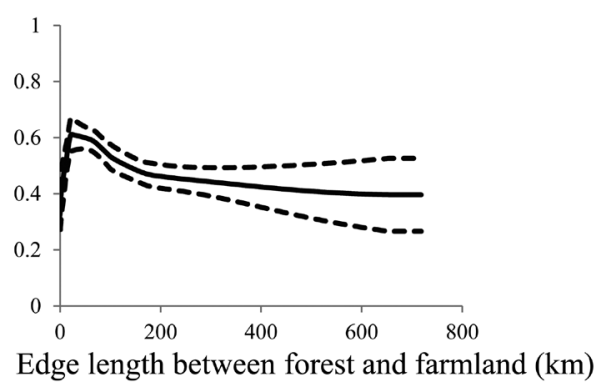

Fig. 2. Relationship between habitat suitability index of the northern goshawk Accipiter gentilis and (a) annual average temperature; (b) PC1 represented proportion of the forest area (c) PC3 represented proportion of urban area and (d) edge length between forest and farmland. Solid lines represent the mean, and dotted lines represent the $95 \%$ confidence interval (CI). 
a.

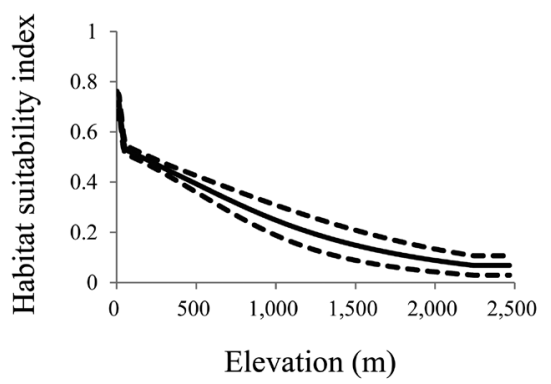

b.

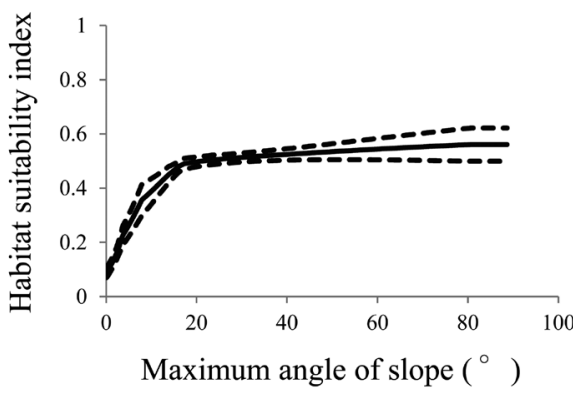

c.

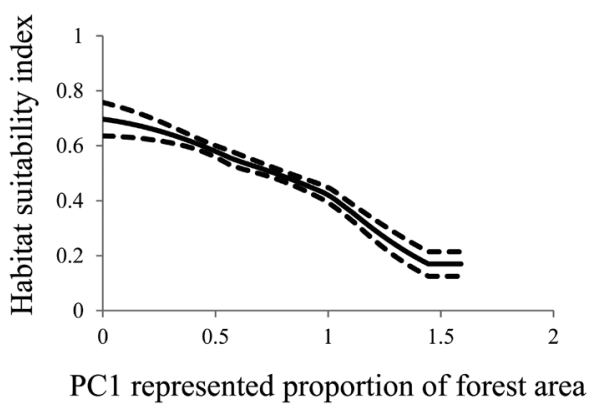

Fig. 3. Relationship between habitat suitability index of the peregrine falcon Falco peregrinus and (a) elevation; (b) maximum angle of the slope; and (c) PC1 represented proportion of forest area. Solid lines represent the mean, and dotted lines represent the $95 \%$ confidence interval $(\mathrm{CI})$.

falcon showed that high-risk areas (more than 0.5 , indicating about $1 \%$ of the grids) were distributed on the plains along the Sea of Japan and Pacific coast (Fig. 4b and 4c). In addition, habitat suitability indices were positively correlated with avian influenza A risk indices (northern goshawk: $r=0.47, P<0.001$; and peregrine falcon: $r=0.54, P<0.001$ ) (Fig. $5 \mathrm{~b}$ and $5 \mathrm{c}$ ). The infected peregrine falcons were found at relatively high-risk areas; on the contrary, the carcasses of the other two species were found at relatively low-risk areas for each species, although only one carcass of each species has been reported (Fig. 4).

\section{DISCUSSION}

The SDMs for raptors could predict the potential distribution of each species and identify high-risk areas for avian influenza A infection. Habitat suitability indices for the mountain hawk-eagle tended to be high at high elevation, with a threshold snow level. Since the mountain hawk-eagle typically lives in mountainous areas with elevation ranging from 100 to $1,100 \mathrm{~m}$ [45], habitat suitability of the species was high in those areas. Mountain hawk-eagles also hunt prey on the ground [45], and habitat suitability had negative relationship with more than $70 \mathrm{~cm}$ snow depth. Therefore, presence of the mountain hawk-eagle was rare in high-risk areas for avian influenza A infection, which tended to be distributed among lowlands [44]. Habitat suitability indices for the northern goshawk were high at high temperature, less forested areas and specific lengths between forest and farmland (about $15-80 \mathrm{~km}$ ). Northern goshawks prefer woodland edge next to open land for hunting; consequently, their home range tends to include small, forested areas [24]. High-risk areas were therefore identified at urban and countryside lowlands along the Pacific coast and western Japan. Habitat suitability indices for the peregrine falcon were high at low elevation, less forested proportions and a specific angle of slope (more than 20 degrees of slope). Abundance of the peregrine falcon was higher along coasts and estuaries usually located lowland $[16,35]$. Coasts sometimes have steep cliffs, in which raptors use for hunting $[17,29]$. High-risk areas for the peregrine falcon were similar to those of the northern goshawk, because their suitable habitats were both distributed along the seacoasts.

Peregrine falcons infected with HPAI-H5N1 were predominantly found in the same high-risk areas predicted by the present study, which is indicative of the reliability of the risk map. Since there was only one case each of the other two species, we could not identify the reliability of their risk maps. However, we suggest that suitable habitats for the mountain hawk-eagle were spatially separated from highrisk areas for the incidence of avian influenza A . On the other hand, despite the high-risk for the incidence of avian influenza $\mathrm{A}$ in the two species, reported fatalities were less for the northern goshawk than they were for the peregrine falcon. One limitation of the model meant that we could not compare risk indices between species with logistic outputs in MaxEnt analysis [12]. Moreover, if the raptors have similar ecological niches, interspecific competition could strongly affect their distribution [54]. Because data on the distribution of competing species are rarely available, we could not consider these effects.

The northern goshawk more frequently inhabits forested areas [47], thereby minimizing the chances of their carcasses being discovered. In contrast, the peregrine falcon spends more time in open land [29, 30]; therefore, it would be relatively easy to find their carcasses. In addition, in comparison to other raptor species, the northern goshawk might have greater resistance against the avian influenza A. Comparisons of resistance among raptors have been rarely examined. To determine the factors that influence resistance, prey species and the levels of resistance against the virus should be investigated in future studies.

Furthermore, the northern goshawk might have fewer opportunities to consume infected prey. Raptors generally 


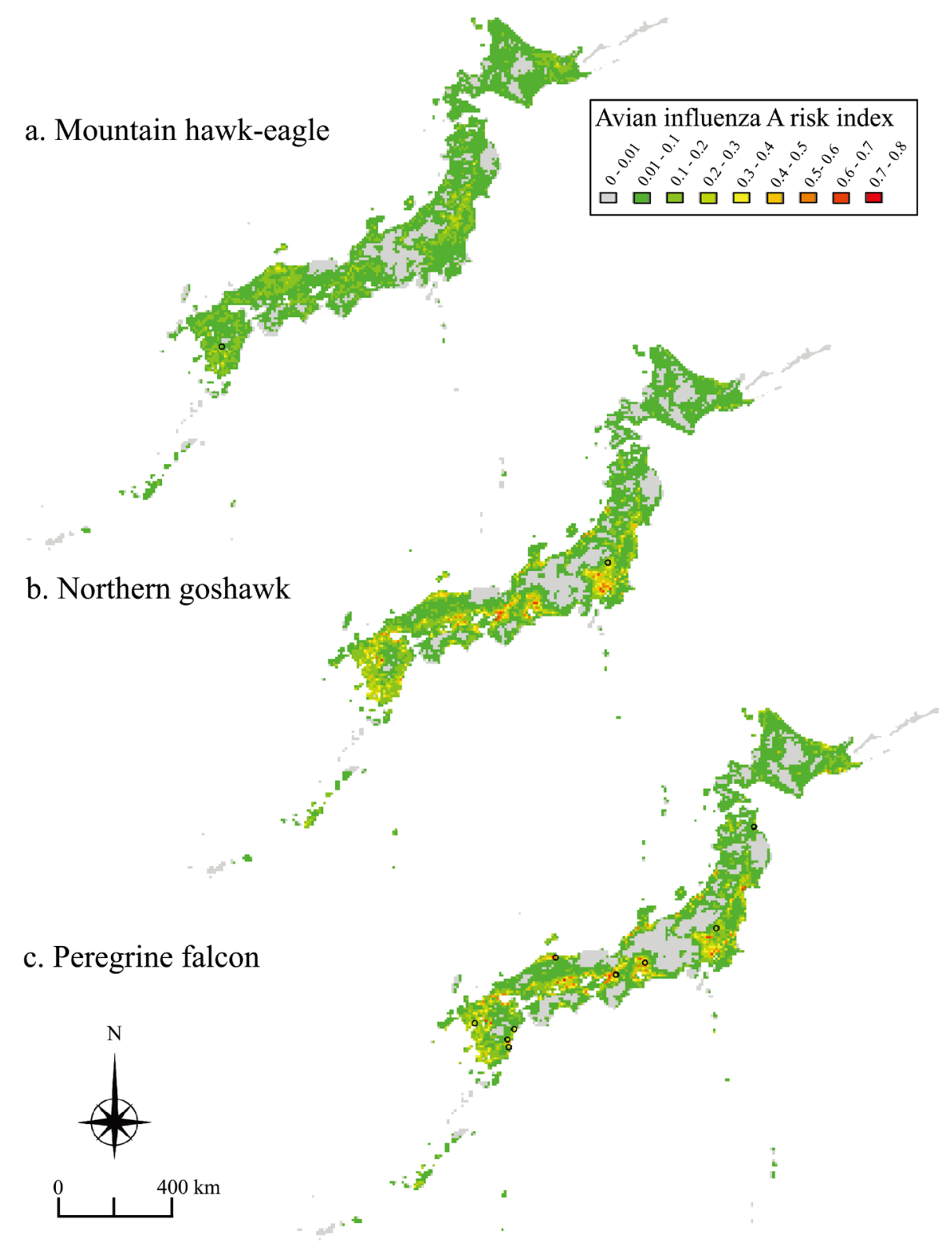

Fig. 4. Avian influenza A risk map for the mountain hawk-eagle Nisaetus nipalensis (a), northern goshawk Accipiter gentilis (b) and peregrine falcon Falco peregrinus (c). Avian influenza A risk indices were calculated using the equation: (avian influenza A risk index) $\times$ (habitat suitability index for each raptor). Black circles indicate sites at which the carcasses of each species infected with HPAI-H5N1 were collected from 2004-2011.

become infected with avian influenza A viruses by feeding on infected prey or carrion $[1,55]$. Since most of the HPAI$\mathrm{H} 5 \mathrm{~N} 1$ infected birds have been waterfowl $[53,55]$, if the northern goshawk had fewer opportunities to hunt, then the results of the present study should be reasonable. In winter, their attacks on ducks have been observed [39]; however, there have been insufficient quantitative data on their prey species during the winter season in Japan [24].

Habitat environment would also be an important factor in defining prey selection. Peregrine falcons mainly attack ducks during the winter at coastal areas in Japan [39]. In addition, they hunt ducks on a daily basis near a lake in Canada [9]. In urban areas of England, the Eurasian teal Anas crecca becomes the second major prey species of peregrine falcons in mid-winter [11]; however, in suburban areas of Japan, Eurasian teals are rarely hunted [15]. Since such diet variability between species and environments can influence incidence risk, analysis of high-risk areas is necessary for 
a) Mountain hawk-eagle

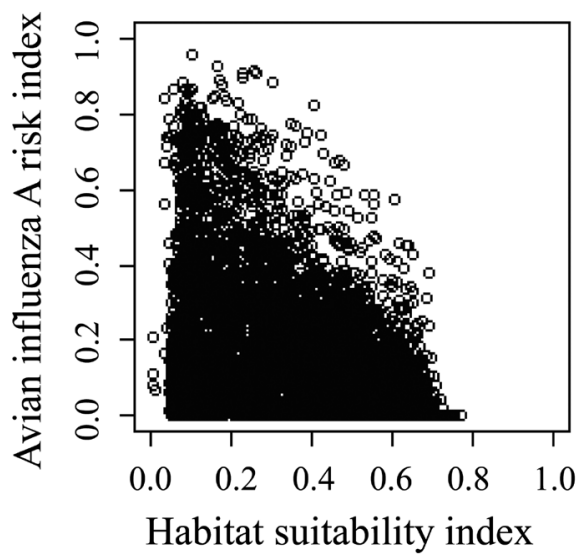

b) Northern goshawk

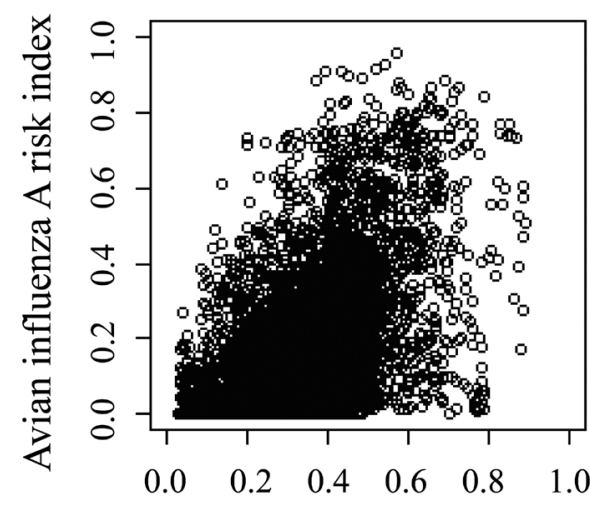

Habitat suitability index

\section{c) Peregrine falcon}

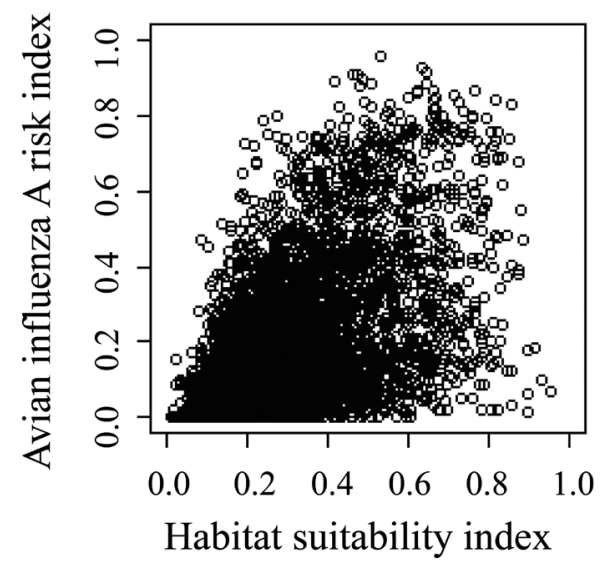

Fig. 5. Relationship between avian influenza risk index and habitat suitability indices of the mountain hawk-eagle (a), northern goshawk (b) and peregrine falcon (c) for each grid cell.

more detailed risk assessment.

In the present study, we investigated spatially high-risk areas for avian influenza $\mathrm{A}$ in each raptor species. We rec- ommend enhanced surveillance for each species at high-risk areas and rapid establishment of inspection systems. At the same time, ecological assessments, such as the composition of prey species and species-specific pathogenic risk, could provide multifaceted insights into the total ecological risks with which endangered species are faced.

ACKNOWLEDGMENTS. We are grateful to the Ministry of the Environment, Japan; the Hokkaido Institute of Environmental Sciences; and Japan Science and Technology Agency for providing the presence data for the raptor species. Finally, we thank the two anonymous reviewers for their insightful comments on the manuscript.

\section{REFERENCES}

1. Bertran, K., Busquets, N., Abad, F. X., García de la Fuente, J., Solanes, D., Cordón, I., Costa, T., Dolz, R. and Majó, N. 2012. Highly (H5N1) and low (H7N2) pathogenic avian influenza virus infection in falcons via nasochoanal route and ingestion of experimentally infected prey. PLoS ONE 7: e32107. [Medline] [CrossRef]

2. Biodiversity Center of Japan 2004. The National Survey on the Natural Environment: Report of the distributional survey of Japanese animals (Birds). Biodiversity Center of Japan, Fujiyoshida.

3. Capua, I. and Alexander, D. 2010. Perspectives on the global threat: the challenge of avian influenza viruses for the world's veterinary community. Avian Dis. 54 Suppl: 176-178. [Medline] [CrossRef]

4. Causey, D. and Edwards, S. V. 2008. Ecology of avian influenza virus in birds. J. Infect. Dis. 197 Suppl 1: S29-S33. [Medline] [CrossRef]

5. Chen, H., Li, Y., Li, Z., Shi, J., Shinya, K., Deng, G., Qi, Q., Tian, G., Fan, S., Zhao, H., Sun, Y. and Kawaoka, Y. 2006. Properties and dissemination of $\mathrm{H} 5 \mathrm{~N} 1$ viruses isolated during an influenza outbreak in migratory waterfowl in western China. $J$. Virol. 80: 5976-5983. [Medline] [CrossRef]

6. Couacy-Hymann, E., Danho, T., Keita, D., Bodjo, S. C., Kouakou, C., Koffi, Y. M., Beudje, F., Tripodi, A., de Benedictis, P. and Cattoli, G. 2009. The first specific detection of a highly pathogenic avian influenza virus (H5N1) in Ivory Coast. Zoonoses Public Health 56: 10-15. [Medline] [CrossRef]

7. Daszak, P., Cunningham, A. A. and Hyatt, A. D. 2000. Emerging infectious diseases of wildlife - threats to biodiversity and human health. Science 287: 443-449. [Medline] [CrossRef]

8. Daszak, P., Cunningham, A. A. and Hyatt, A. D. 2003. Infectious disease and amphibian population declines. Divers. Distrib. 9: 141-150. [CrossRef]

9. Dekker, D. 1987. Peregrine falcon predation on ducks in Alberta and British Columbia. J. Wildl. Manage. 51: 156-159. [CrossRef]

10. Dixon, M. A., Dar, O. A. and Heymann, D. L. 2014. Emerging infectious diseases: opportunities at the human-animal-environment interface. Vet. Rec. 174: 546-551. [Medline] [CrossRef]

11. Drewitt, E. J. and Dixon, N. 2008. Diet and prey selection of urban-dwelling Peregrine falcons in southwest England. $B r$. Birds 101: 58-67.

12. Elith, J., Phillips, S. J., Hastie, T., Dudik, M., Chee, Y. E. and Yates, C. J. 2011. A statistical explanation of MaxEnt for ecologists. Divers. Distrib. 17: 43-57. [CrossRef]

13. Elith, J., Graham, C. H., Anderson, R. P., Dudík, M., Ferrier, 
S., Guisan, A., Hijmans, R. J., Huettmann, F., Leathwick, J. R., Lehmann, A., Li, J., Lohmann, L. G., Loiselle, B. A., Manion, G., Moritz, C., Nakamura, M., Nakazawa, Y., Overton, J. M., Peterson, A. T., Phillips, S. J., Richardson, K., Scachetti-Pereira, R., Schapire, R. E., Soberón, J., Williams, S., Wisz, M. S. and Zimmermann, N. E. 2006. Novel methods improve prediction of species' distributions from occurrence data. Ecography 29: 129-151. [CrossRef]

14. Environmental Agency of Japan 1997. Natural environmental information GIS (CD-ROM). Environmental Agency of Japan, Tokyo.

15. Ezaki, Y. and Mizota, H. 2006. Wintering of a Peregrine Falcon on an electricity pylon and its food in a suburban area of western Japan. Ornitholog. Sci. 5: 211-216. [CrossRef]

16. Ferrer-Sánchez, Y. and Rodríguez-Estrella, R. 2015. Man-made environments relationships with island raptors: endemics do not cope with habitat changes, the case of the island of Cuba. Biodivers. Conserv. 24: 407-425. [CrossRef]

17. Gainzarain, J. A., Arambarri, R. and Rodríguez, A. F. 2000. Breeding density, habitat selection and reproductive rates of the Peregrine Falcon Falco peregrinus in Álava (northern Spain). Bird Study 47: 225-231. [CrossRef]

18. Gauthier-Clerc, M., Lebarbenchon, C. and Thomas, F. 2007. Recent expansion of highly pathogenic avian influenza H5N1: a critical review. Ibis 149: 202-214. [CrossRef]

19. Hall, J. S., Ip, H. S., Franson, J. C., Meteyer, C., Nashold, S., TeSlaa, J. L., French, J., Redig, P. and Brand, C. 2009. Experimental infection of a North American raptor, American Kestrel (Falco sparverius), with highly pathogenic avian influenza virus (H5N1). PLoS ONE 4: e7555. [Medline] [CrossRef]

20. Harvell, C. D., Kim, K., Burkholder, J. M., Colwell, R. R., Epstein, P. R., Grimes, D. J., Hofmann, E. E., Lipp, E. K., Osterhaus, A. D. M. E., Overstreet, R. M., Porter, J. W., Smith, G. W. and Vasta, G. R. 1999. Emerging marine diseases - climate links and anthropogenic factors. Science 285: 1505-1510. [Medline] [CrossRef]

21. Hernandez, P. A., Graham, C. H., Master, L. L. and Albert, D. L. 2006. The effect of sample size and species characteristics on performance of different species distribution modeling methods. Ecography 29: 773-785. [CrossRef]

22. Hijmans, R. J., Cameron, S. E., Parra, J. L., Jones, P. G. and Jarvis, A. 2005. Very high resolution interpolated climate surfaces for global land areas. Int. J. Climatol. 25: 1965-1978. [CrossRef]

23. Hokkaido Institute of Environmental Sciences and Japan Science and Technology Agency 2004. BirdBase, http://birdbase. ies.hro.or.jp/1_eng/index.html. Accessed July 2014.

24. Horie, R. and Ozaki, K. 2008. Home range of Northern goshawk. pp. 33-39. In: Ecology and Conservation of Northern Goshawk (Ozaki, K. and Endo, K. eds.), Japan Forest Technology Association, Tokyo. (In Japanese).

25. Iida, T., Iida, S., Mohri, T. and Inoue, S. 2007. Long-term changes in forest vegetation as a factor for decreasing breeding success of the Mountain Hawk Eagle Spizaetus nipalensis. Jpn. J. Ornithol. 56: 141-156 (In Japanese with English abstract). [CrossRef]

26. International Union for Conservation of Nature and Natural Resources (IUCN) 2011. The IUCN red list of threatened species. Version 2011.2. http://www.iucnredlist.org Accessed July 2014.

27. Ito, T. 2009. [Highly pathogenic avian influenza and wild birds]. Uirusu 59: 53-58 (In Japanese with English abstract). [Medline] [CrossRef]

28. Japan Meteorological Agency 2002. Mesh climatic data 2000
(CD-ROM). Japan Meteorological Agency, Tokyo.

29. Jenkins, A. R. 2000. Hunting mode and success of African Peregrines Falco peregrinus minor, does nesting habitat quality affect foraging efficiency? Ibis 142: 235-246. [CrossRef]

30. Jenkins, A. R. and Benn, G. A. 1998. Home range size and habitat requirements of Peregrine falcons on the Cape peninsula. $J$. Raptor Res. 32: 90-97.

31. Keawcharoen, J., van Riel, D., van Amerongen, G., Bestebroer, T., Beyer, W. E., van Lavieren, R., Osterhaus, A. D., Fouchier, R. A. M. and Kuiken, T. 2008. Wild ducks as long-distance vectors of highly pathogenic avian influenza virus (H5N1). Emerg. Infect. Dis. 14: 600-607. [Medline] [CrossRef]

32. Kilpatrick, A. M., Chmura, A. A., Gibbons, D. W., Fleischer, R. C., Marra, P. P. and Daszak, P. 2006. Predicting the global spread of H5N1 avian influenza. Proc. Natl. Acad. Sci. U.S.A. 103: 19368-19373. [Medline] [CrossRef]

33. Kim, H. R., Lee, Y. J., Park, C. K., Oem, J. K., Lee, O. S., Kang, H. M., Choi, J. G. and Bae, Y. C. 2012. Highly pathogenic avian influenza (H5N1) outbreaks in wild birds and poultry, South Korea. Emerg. Infect. Dis. 18: 480-483. [Medline] [CrossRef]

34. Kuiken, T. 2013. Is low pathogenic avian influenza virus virulent for wild waterbirds? Proc. Biol. Sci. 280: 20130990. [Medline] [CrossRef]

35. Lee, S. 2013. Distribution and abundance of wintering raptors in the Korean peninsula. J. Ecol. Environ. 36: 211-216. [CrossRef]

36. Marjuki, H., Wernery, U., Yen, H. L., Franks, J., Seiler, P., Walker, D., Krauss, S. and Webster, R. G. 2009. Isolation of highly pathogenic avian influenza H5N1 virus from Saker falcons (Falco cherrug) in the Middle East. Adv. Virol. 2009: 1. [Medline] [CrossRef]

37. Marston, H. D., Folkers, G. K., Morens, D. M. and Fauci, A. S. 2014. Emerging viral diseases: confronting threats with new technologies. Sci. Transl. Med. 6: 253ps10. [Medline] [CrossRef]

38. Matsue, M., Momose, H., Ueta, M. and Fujiwara, N. 2006. Factors affecting the breeding density of Northern Goshawks (Accipiter gentilis). J. Jpn. Inst. Landsc. Archit. 69: 513-518 (In Japanese with English abstract). [CrossRef]

39. Matsumura, T. 1993. Predatory behavior and interspecific relationships of raptors in the non-breeding season in regenerated habitat. Strix 12: 61-71 (In Japanese with English abstract).

40. Ministry of the Environment Japan, 2012. The fourth Red List. http://www.biodic.go.jp/rdb/rdb_f.html. Accessed July 2014.

41. Ministry of Land Infrastructure, Transport and Tourism of Japan, 1981. Third mesh data for elevation and slope angle. http://nlftp. mlit.go.jp/ksj/gml/datalist/KsjTmplt-G04-a.html. Accessed July 2014.

42. Mitsukuri, K., Takahashi, M., Nagamine, K. and Ueda, T. 2006. Observations of breeding activity of Peregrine falcons Falco peregrinus in Etomo Peninsula, south-eastern Hokkaido. J. Yamashina Inst. Ornithol. 37: 147-152. [CrossRef]

43. Morens, D. M., Folkers, G. K. and Fauci, A. S. 2004. The challenge of emerging and re-emerging infectious diseases. Nature 430: 242-249. [Medline] [CrossRef]

44. Moriguchi, S., Onuma, M. and Goka, K. 2013. Potential risk map for avian influenza A virus invading Japan. Divers. Distrib. 19: 78-85. [CrossRef]

45. Morimoto, S. and Iida, T. 1992. Ecology and preservation of Hodgson's Hawk-Eagles. Strix 11: 59-90 (In Japanese with English abstract).

46. Nanami, Y., Tago, K., Torii, Y. and Kashiwabara, S. 2006. Estimation of potential hunting area of Mountain Hawk Eagle 
Spizaetus nipalensis. Ecol. Civil Eng. 9: 21-30 (In Japanese with English abstract). [CrossRef]

47. Ozaki, K. and Horie, R. 2008. Habitat environment and habitat selection of Northern goshawk. pp. 40-47. In: Ecology and Conservation of Northern Goshawk, (Ozaki, K. and Endo, K. eds.), Forest Technology Association, Tokyo. (In Japanese).

48. Peterson, A. T. 2006. Ecologic niche modeling and spatial patterns of disease transmission. Emerg. Infect. Dis. 12: 1822-1826. [Medline] [CrossRef]

49. Phillips, S. J., Anderson, R. P. and Schapire, R. E. 2006. Maximum entropy modeling of species geographic distributions. Ecol. Modell. 190: 231-259. [CrossRef]

50. Phillips, S. J., Dudík, M., Elith, J., Graham, C. H., Lehmann, A., Leathwick, J. and Ferrier, S. 2009. Sample selection bias and presence-only distribution models: implications for background and pseudo-absence data. Ecol. Appl. 19: 181-197. [Medline] [CrossRef]

51. R Development Core Team 2011. R: A language and environment for statistical computing. http://www.r-project.org. Accessed July 2014.

52. Roberton, S. I., Bell, D. J., Smith, G. J. D., Nicholls, J. M., Chan, K. H., Nguyen, D. T., Tran, P. Q., Streicher, U., Poon, L. L. M., Chen, H., Horby, P., Guardo, M., Guan, Y. and Peiris, J. S. M. 2006. Avian influenza H5N1 in viverrids: implications for wildlife health and conservation. Proc. Biol. Sci. 273: 1729-1732. [Medline] [CrossRef]

53. Sakoda, Y., Ito, H., Uchida, Y., Okamatsu, M., Yamamoto, N., Soda, K., Nomura, N., Kuribayashi, S., Shichinohe, S., Sunden, Y., Umemura, T., Usui, T., Ozaki, H., Yamaguchi, T., Murase, T., Ito, T., Saito, T., Takada, A. and Kida, H. 2012. Reintroduction of H5N1 highly pathogenic avian influenza virus by migratory water birds, causing poultry outbreaks in the 2010-2011 winter season in Japan. J. Gen. Virol. 93: 541-550. [Medline] [CrossRef]

54. Sarà, M. 2014. Spatial analysis of lanner falcon habitat preferences: Implications for agro-ecosystems management at landscape scale and raptor conservation. Biol. Conserv. 178: 173-184. [CrossRef]

55. Soda, K., Ito, H., Usui, T., Nagai, Y., Ozaki, H., Yamaguchi, T. and Ito, T. 2013. Incursion and spread of H5N1 highly pathogenic avian influenza viruses among wild birds in 2010-11 winter in Japan. J. Vet. Med. Sci. 75: 605-612. [Medline] [CrossRef]

56. Takano, S. 1982. A field guide to the birds of Japan. Wild Bird Society of Japan, Tokyo. (In Japanese).

57. Takekawa, J. Y., Prosser, D. J., Newman, S. H., Bin Muzaffar, S., Hill, N. J., Yan, B. P., Xiao, X. M., Lei, F. M., Li, T. X., Schwarzbach, S. E. and Howell, J. A. 2010. Victims and vectors: highly pathogenic avian influenza $\mathrm{H} 5 \mathrm{~N} 1$ and the ecology of wild birds. Avian Biol. Res. 3: 51-73. [CrossRef]

58. Uchida, H., Takayanagi, S., Suzuki, S., Watanabe, T., Ishimatsu, Y., Tanaka, I., Aoyama, S., Nakamura, H., Noumi, M., Nakajima, H. and Sakurai, M. 2007. Breeding ecology of Northern Goshawk at hilly terrain area in central Japan. Jpn. J. Ornithol. 56: 131-140. [CrossRef]

59. van Gils, J. A., Munster, V. J., Radersma, R., Liefhebber, D., Fouchier, R. A. M. and Klaassen, M. 2007. Hampered foraging and migratory performance in swans infected with low-pathogenic avian influenza A virus. PLOS ONE 2: e184. [Medline] [CrossRef]

60. van Riper, C., van Riper, S. G., Goff, M. L. and Laird, M. 1986. The epizootiology and ecological significance of Malaria in Hawaiian land birds. Ecol. Monogr. 56: 327-344. [CrossRef]

61. Wang, J., Vijaykrishna, D., Duan, L., Bahl, J., Zhang, J. X., Webster, R. G., Peiris, J. S. M., Chen, H., Smith, G. J. D. and Guan, Y. 2008. Identification of the progenitors of Indonesian and Vietnamese avian influenza A ( $\mathrm{H} 5 \mathrm{~N} 1)$ viruses from southern China. J. Virol. 82: 3405-3414. [Medline] [CrossRef]

62. Webster, R. G., Bean, W. J., Gorman, O. T., Chambers, T. M. and Kawaoka, Y. 1992. Evolution and ecology of influenza A viruses. Microbiol. Rev. 56: 152-179. [Medline]

63. Wikelski, M., Foufopoulos, J., Vargas, H. and Snell, H. 2004. Galápagos birds and diseases: invasive pathogens as threats for island species. Ecol. Soc. 9: 5.

64. Yackulic, C. B., Chandler, R., Zipkin, E. F., Royle, J. A., Nichols, J. D., Grant, E. H. C. and Veran, S. 2013. Presence-only modelling using MAXENT: when can we trust the inferences? Methods Ecol. Evol. 4: 236-243. [CrossRef] 